\title{
Ion channel inhibitors block caspase activation by mechanisms other than restoring intracellular potassium concentration
}

\author{
E Benítez-Rangel ${ }^{1}$, L García', MC Namorado² ${ }^{1}$ JL Reyes $^{2}$ and A Guerrero-Hernández ${ }^{\star, 1}$
}

Ion fluxes at the plasma membrane have an important role in early stages of apoptosis. Accordingly, plasma membrane depolarization and gain of $\mathrm{Na}^{+}$and loss of $\mathrm{K}^{+}$are initial events in apoptosis. We have studied the effect of staurosporine (STS), a well-established apoptosis inducer, on the membrane potential of HeLa cells to determine the nature of STS-activated ion conductances and their role in the activation of different caspases. We observed that STS can activate tetraethylammonium $\left(\mathrm{TEA}^{+}\right)$and 4-aminopyridine-sensitive $\mathrm{K}^{+}$channels and flufenamic-sensitive cation channels as an early response. The combination of these ion channel inhibitors significantly reduced cytochrome $c$ (cyt $c$ ) release and activation of caspase-9, -3 and -8 . STS also induced a large reduction in the intracellular $\left[\mathrm{K}^{+}\right]$that was not blocked by the ion channel inhibitors. Our data suggest that reduction in the $\left[\mathrm{K}^{+}\right]_{\mathrm{i}}$ is necessary but not sufficient and that ion channel inhibitors block activation of caspase-3 by two different mechanisms: the inhibitors of $\mathrm{K}^{+}$channels by reducing cyt $\boldsymbol{c}$ release while flufenamic acid by a different, unrelated mechanism that does not involve cation channels at the plasma membrane. Our data also imply that these ion channels activated by STS are not responsible for the reduction in the $\left[\mathrm{K}^{+}\right]_{i}$ associated with apoptosis.

Cell Death and Disease (2011) 2, e113; doi:10.1038/cddis.2010.93; published online 13 January 2011

Subject Category: Cancer

Cell transformations associated with apoptosis result from the biochemical action of an execution program, whose main characteristic is activation of caspases. ${ }^{1}$ Different inducers of apoptosis trigger plasma membrane potential (PMP) depolarization $^{2}$ while the inhibition of apoptosis by $\mathrm{Bcl}-2$ and $\mathrm{Mcl}-1$ is associated with PMP hyperporlarization. ${ }^{3,4}$ It has been shown that ion fluxes, particularly $\mathrm{K}^{+}$efflux, have a key role in apoptosis. The activation of both $\mathrm{K}^{+5,6}$ and $\mathrm{Cl}^{-}$channels is necessary for apoptotic volume decrease (AVD) or cell shrinkage and also for activation of caspases. ${ }^{7,8}$ It has been shown that, before AVD, there is an initial movement of monovalent ions. Although the inhibition of $\mathrm{Cl}^{-}$channels while inhibiting AVD, does not always reduce activation of caspases. ${ }^{9}$ Different inducers of apoptosis trigger both accumulation of intracellular $\mathrm{Na}^{+}$and loss of intracellular $\mathrm{K}^{+2,7,10-13}$ and these events are associated with PMP depolarization. ${ }^{2}$ It has been also shown that the reduction in the intracellular $\left[\mathrm{K}^{+}\right]$and PMP depolarization are a late event since involve inhibition of $\mathrm{Na}^{+} / \mathrm{K}^{+}$pump by caspase-mediated degradation of its $\beta$-subunit. 2,14

Nevertheless, the activation of caspases requires the reduction of the $\left[\mathrm{K}^{+}\right]_{\mathrm{i}}$ regardless the inducer of apoptosis used or cell type studied. ${ }^{13,15-17}$ High external $\left[\mathrm{K}^{+}\right]$inhibits both the extrinsic (Fas-mediated) and the intrinsic (etoposideinduced) cell death programs apparently by inhibiting the release of cytochrome $c$ (cyt $c$ ) from mitochondria. ${ }^{17}$ However, it has been shown that staurosporine (STS)-induced cyt $c$ release in both HeLa and neuroblastoma cells (SK-N-BE(2)) is not inhibited by avoiding reduction of $\left[\mathrm{K}^{+}\right]_{\mathrm{i}}{ }^{16}$ Actually, it appears that high intracellular $\mathrm{K}^{+}$protects against apoptosis by inhibiting the apoptosome assembly. ${ }^{13,16,18}$ Apparently, the procaspase- 3 activity is inhibited by high $\left[\mathrm{K}^{+}\right]$because its activity decrease to $\sim 50 \%$ in $\left[\mathrm{K}^{+}\right.$] above $25 \mathrm{mM} \mathrm{K}$, in contrast mature caspase- 3 activity is unaltered by reducing $\left[\mathrm{K}^{+}\right]{ }^{18}$ Recently, it has been suggested that the apoptosome assembly is regulated by ion strength more than a direct effect of $\mathrm{K}^{+}$per se. ${ }^{15,16}$

STS, a non-selective kinase inhibitor that has a strong apoptotic action, activates $\mathrm{K}^{+}$currents $^{5}$ and also induces PMP depolarization, which has been reported to depend on both depolarization of mitochondrial membrane potential (MMP) and activation of caspase-3 (Bortner et al. ${ }^{2}$; Dussmann et al. ${ }^{14}$ ). We have studied the effect of STS on PMP and ion channels inhibitors on the activity of caspases in HeLa cells. Our data suggest that STS activates both $\mathrm{K}^{+}$and cation channels and that $\left[\mathrm{K}^{+}\right]_{\mathrm{i}}$ reduction is required for caspase activation, particularly caspase-3. Ion channel inhibitors while blocking activation of caspase-3 do not block STS-induced reduction in $\left[\mathrm{K}^{+}\right]_{\mathrm{i}}$ implying that STS-induced $\mathrm{K}^{+}$loss is not occurring by these ion channels activated by STS.

\footnotetext{
${ }^{1}$ Department of Biochemistry, CINVESTAV-IPN, DF, México and ${ }^{2}$ Department of Physiology, Biophysics and Neuroscience, CINVESTAV-IPN, DF, México *Corresponding author: A Guerrero-Hernández, Departamento de Bioquímica, CINVESTAV-IPN, Apdo. Postal, 14-740, DF, México. Tel: +52 55 50613950; Fax: + 525550613391 ; E-mail: aguerrero@ cinvestav.mx

Keywords: plasma membrane potential; potassium channels; caspases; flufenamic; cytochrome $c$ release; apoptosis

Abbreviations: AVD, apoptotic volume decrease; COX, cyclo oxygenase; cyt c, cytochrome c; FA or F, flufenamic acid; Gram, gramicidin; TEA ${ }^{+}$or $\mathrm{T}_{\text {, }}$ tetraethylammonium; 4AP or 4, 4-aminopyridine; PMP, plasma membrane potential; STS, staurosporine

Received 29.9.10; revised 22.11.10; accepted 29.11.10; Edited by V De Laurenzi
} 


\section{Results}

High external $\mathrm{K}^{+}$inhibits STS-induced activation of caspases. Caspases are the main effectors in apoptosis, particularly caspase-3. Incubation of cells with $1 \mu \mathrm{M}$ STS for a period of $4 \mathrm{~h}$ induced a significant activation of caspases-9, -3 and -8 in HeLa cells (Figure 1). This time period of $4 \mathrm{~h}$ was chosen because STS induced the maximal activation of caspase-3 and cyt $c$ release (Supplementary Figure 3). STS-induced caspase-3 activation was much larger when compared with other apoptosis inducers, such as $\mathrm{H}_{2} \mathrm{O}_{2}$ and thapsigargin (not shown). Under our assay conditions (cells were in serum-free culture medium for $24 \mathrm{~h}$ ) both caspase- 9 and caspase- 8 displayed a larger basal activity than caspase-3 when compared with the corresponding maximal response obtained with STS. Interestingly, STS induced a significant activation of caspase-8, the main effector of the extrinsic pathway in apoptosis. Caspase-8 can be activated by caspase-3 (Tang et al. ${ }^{19}$ ) but also the reverse has been described. ${ }^{20}$ Incubation of cells for $4.5 \mathrm{~h}$ in 5,70 or $140 \mathrm{~K}$ saline solutions (see Materials and Methods section) did not change the basal activity of these three caspases (not shown). However, STS-induced activation of all three caspases was significantly inhibited by $70 \mathrm{~K}$ solution in approximately $60 \%$ (Figure 1). Interestingly, $140 \mathrm{~K}$ solution totally abolished the effect of STS on all three caspases (Figure 1). These data confirm the importance of $\mathrm{K}^{+}$ reduction in the activation of these three caspases. We next studied whether STS could activate ion channels that would function as the exit pathway for $\mathrm{K}^{+}$ions.

STS induces an early activation of ion channels at the plasma membrane. To study the ion conductance activated by STS, we incubated HeLa cells with bisoxonol. For all and each experiment, we determined first the resting PMP by

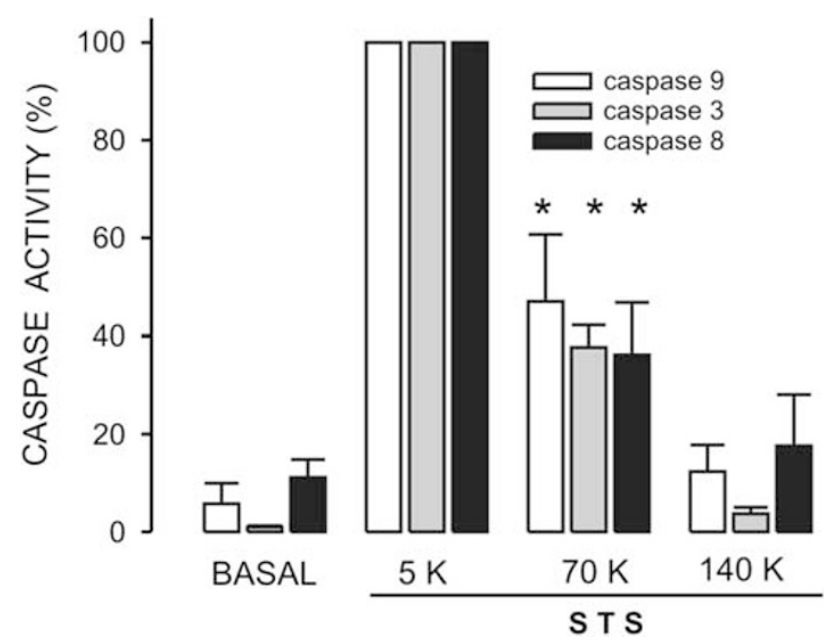

Figure 1 High extracellular $\left[\mathrm{K}^{+}\right]$inhibits activation of caspases by STS in HeLa cells. Caspase $-9,-3$ and -8 activities were assessed as indicated in Materials and Methods section. The caspase inhibitor-corrected fluorescence signal induced by STS was taken as $100 \%$ for each caspase. STS activated caspase $-9,-8$ and -3 about $20-, 10-$ and 100 -fold, respectively. This activation was significantly inhibited by preincubating cells for $30 \mathrm{~min}$ in 70 or $140 \mathrm{~K}$ solutions. $n=5 .{ }^{*} P<0.05$ increasing the activity of $\mathrm{K}^{+}$channels with histamine (Supplementary Figure 2). This agonist via $\mathrm{H}_{1}$ receptors induces the increase in inositol trisphosphate levels, $\mathrm{Ca}^{2+}$ release and the activation of $\mathrm{Ca}^{2+}$-dependent intermediate conductance $\mathrm{K}^{+}$channels. ${ }^{21}$ This maneuver sets the PMP at the reversal potential for $\mathrm{K}^{+}$channels and we used this gradient to determine resting PMP. As histamine-induced $\mathrm{K}^{+}$ conductance becomes the predominant one, we can use Nernst equation to calculate resting PMP. HeLa cells had an average resting PMP of $-60 \pm 1.1 \mathrm{mV}(n=76)$, these data were close to the resting PMP $(-51 \pm 2.4 \mathrm{mV})$ observed using patch clamp technique. ${ }^{22,23}$ The similar values for PMPs obtained with these two different approaches support the idea that bisoxonol is a reliable indicator to estimate PMP changes in HeLa cells during apoptosis.

It has been reported that STS induces an elevation of $\mathrm{K}^{+}$ channel activity in PASMC cells ${ }^{5}$ and in other types of cells. ${ }^{24}$ To determine whether STS activates ion channels in HeLa cells, we have studied the effect of this apoptosis inducer on PMP within the first 10 min of STS addition (Figure 2). This time window was selected because it allowed the stabilization of STS-induced PMP changes. Although, STS always changed PMP in few minutes, the type and magnitude of the responses were variable. Most of the experiments $(60 \%)$ displayed STS-induced depolarization of PMP (Figure 2a, dashed line) while the rest showed plasma membrane hyperpolarization that was either sustained (Figure 2a, dotted line) or transient (Figure 2a, solid line). This hyperpolarization increased PMP by approximately $20 \mathrm{mV}(-79.7 \pm 2.9 \mathrm{mV}$, $n=28$, Figure 2c, fourth open bar) and the depolarization response to STS involved a $20 \mathrm{mV}$ decreased in PMP $(-39.4 \pm 1.7 \mathrm{mV}, n=47$, Figure $2 \mathrm{c}$, fourth closed bar). The application of DMSO alone did not modify PMP $(-53.5 \pm 3 \mathrm{mV}, n=13$, not shown). These data show two different types of PMP responses to STS that we called $D$ or $\mathrm{H}$ when at the end of the 10-min recording period; the PMP was either above or below the resting membrane potential, respectively. However, the resting PMP was practically the same between cells having the $H$ or $D$ responses (Figure $2 \mathrm{c}$, first bars). PMP for cells having $D$ response was $-59.2 \pm 1.3 \mathrm{mV}(n=47$, closed bar) and for cells showing $\mathrm{H}$ response was $-61 \pm 2 \mathrm{mV}$ ( $n=28$, open bar). To assess whether the effect of STS was due to the increase in ion channel activity, we determined the effect of STS on the capability of gramicidin (Gram) to depolarize HeLa cells (Figures $2 a$ and $b$ ). STS reduced the depolarization effect of Gram $(2.1 \pm 0.4 \mathrm{mV}, n=28)$ for either $\mathrm{D}(-5.4 \pm 1.5 \mathrm{mV}$, $n=29)$ or $\mathrm{H}(-24 \pm 9.2 \mathrm{mV}, n=11)$ type of responses, implying that STS is activating ion channels. Collectively, these data suggest that STS activates different types of ion channels as an early response in HeLa cells.

It has been reported that PMP depolarization is associated with apoptosis. ${ }^{2,14}$ However, it has been suggested that this PMP depolarization occurs after activation of caspase ${ }^{14}$ and is partly due to $\mathrm{Na}^{+} / \mathrm{K}^{+}$ATPase degradation., ${ }^{2,14}$ To determine whether caspases were responsible for this effect on PMP, HeLa cells were incubated with $50 \mu \mathrm{M}$ of Z-VAD-fmk. This pan-caspase inhibitor did not reduce $S T S$-induced depolarization response $(-24.9 \pm 2.8 \mathrm{mV}, n=15)$. Additionally, we studied whether inhibition of $\mathrm{Na}^{+} / \mathrm{K}^{+}$ATPase could 

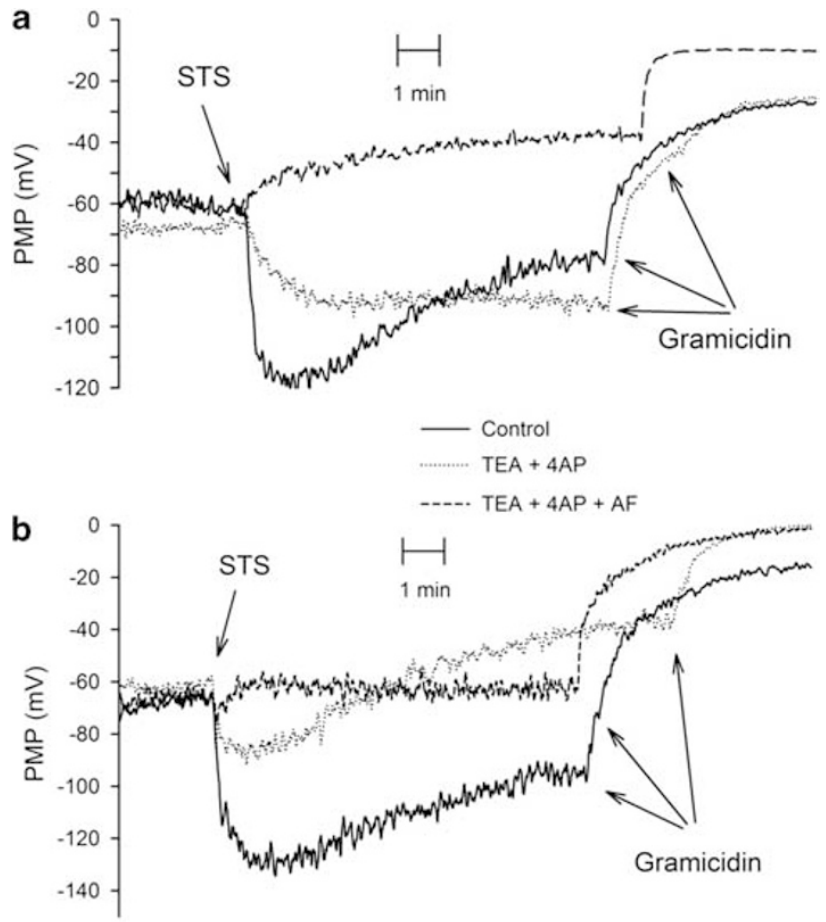

c

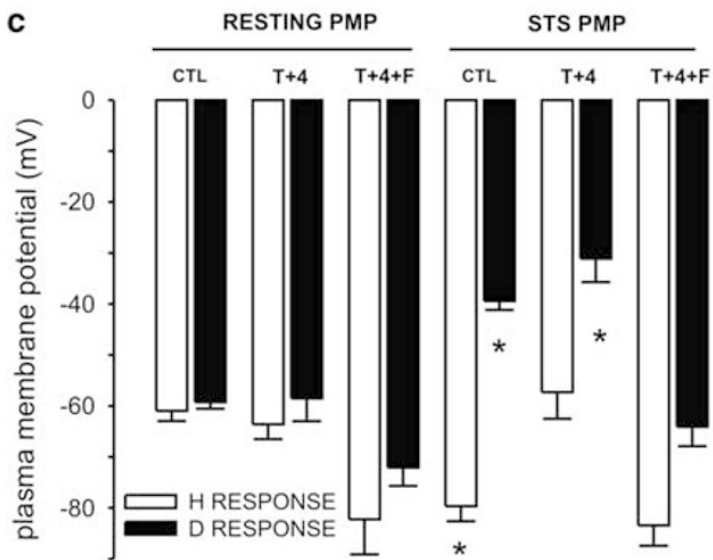

Figure 2 STS alters PMP as an early response in HeLa cells. (a) Cells loaded with bisoxonol to follow PMP were exposed to $1 \mu \mathrm{M}$ STS at the time indicated inducing membrane depolarization (dashed line, $n=48$ ), hyperporlarization (dotted line) or a mixed response (solid line), $n=28$ for both conditions. Once the fluorescence signal has stabilized, Gram was added as depolarization control. Depending whether the PMP finished above or below resting PMP (i.e., PMP before application of STS) were defined either depolarization (D) or hyperpolarization $(H)$, respectively. These records show PMP responses of cells from three different passages, we do not know why the ion channels responding to STS vary among different passages. (b) Cells incubated in either TEA ${ }^{+}$and $4 \mathrm{AP}$ or the combination of TEA ${ }^{+}, 4 \mathrm{AP}$ and FA were exposed to STS were indicated. A mixed response (solid line, $n=26$ ) became depolarizing response by the addition of $\mathrm{TEA}^{+}$and 4AP to inhibit $\mathrm{K}^{+}$channels (dotted line, $n=12$ ). The combination of all three ion channels inhibitors blocked completely the STS-induced changes in PMP (dashed line, $n=14$ ). (c) Average resting PMP and the effect of ion channels inhibitors for cells that respond to STS with either hyperpolarization (white bars) or depolarization (dark bars) depicted as CTL. TEA ${ }^{+}$and 4AP did not affect resting PMP but inhibited the STS-induced hyperpolarization, particularly for $\mathrm{H}$ responses and favored $D$ responses. Notice that the combination of TEA ${ }^{+}, 4 \mathrm{AP}$ and FA-induced hyperpolarization of the resting PMP and totally abolished the STS-induced PMP changes. In this figure, ${ }^{*} P<0.05$ with respect to the corresponding resting PMP. From left to right $n=26,47,8,12,3,9,28,48,8$, 12,3 and 14 respectively explain the STS-induced depolarization. Incubating cells with $100 \mu \mathrm{M}$ ouabain, a Na${ }^{+} / \mathrm{K}^{+}$ATPase inhibitor, produced PMP depolarization in few minutes $(-28.8 \pm 3.1 \mathrm{mV}, n=10)$, in this case Gram-induced membrane depolarization $(1.9 \pm 0.4 \mathrm{mV}$, $n=8$ ), which was similar to the one obtained in cells without STS $(2.1 \pm 0.4 \mathrm{mV}, n=28)$, implying that ouabain-induced PMP depolarization was not because of the opening of ion channels but the inhibition of $\mathrm{Na}^{+} / \mathrm{K}^{+}$pump. The application of STS after ouabain-induced membrane depolarization still produced either depolarization or hyperpolarization of PMP because it was $-20.5 \pm 3.1 \mathrm{mV}(n=8)$ or $-59.1 \pm 8.1 \mathrm{mV}$ $(n=12)$, respectively. All these data indicate that the effect of STS on PMP cannot be explained by inhibition of $\mathrm{Na}^{+} / \mathrm{K}^{+}$ ATPase at this time window.

It has been shown that STS induces an increase in the activity of plasma membrane $\mathrm{K}^{+}$channels, which are sensitive to tetraethylammonium $\left(\mathrm{TEA}^{+}\right)$and 4-aminopyridine (4AP). ${ }^{24}$ To test whether this was the case in HeLa cells, we studied the effect of these inhibitors on the STS-induced changes in PMP (Figure $2 b$, dotted line). These $\mathrm{K}^{+}$channel inhibitors $(\mathrm{T}+4)$ did not modify resting PMP (Figure 2c, second bars). However, The STS-induced hyperpolarization was strongly inhibited by the combination of TEA ${ }^{+}$and 4AP because PMP in the presence of STS $(-57.3 \pm 5.2 \mathrm{mV}, n=8)$ was practically the same as the resting PMP in the presence of these inhibitors $(-63.6 \pm 2.9 \mathrm{mV}, n=8$; Figure $2 \mathrm{~b}$, dotted line and Figure 2c, sixth open bar). In the case of cells showing $D$ responses, these ion channels inhibitors made STS-induced membrane depolarization slightly larger $-31.1 \pm 4.6 \mathrm{mV} \quad(n=12$, Figure 2c, sixth closed bar) from a resting PMP of $-58.5 \pm 4.5 \mathrm{mV}(n=12)$. These data imply that STS activates $\mathrm{K}^{+}$channels, mainly in cells displaying the $\mathrm{H}$ type of response, while cells with $D$ type of response appear to have a poor activity of STS-induced $\mathrm{K}^{+}$channels. These data suggest that STS activates cation channels in those cells having depolarization responses. To study this situation, we used low concentration $(50 \mu \mathrm{M})$ of flufenamic acid (FA or $\mathrm{F})$ to inhibit cation channels. FA increased the resting PMP, reaching the value of $-72.1 \pm 3.6 \mathrm{mV},(n=7$, Figure $2 \mathrm{c}$, third closed bar). The last result implies that FA had a hyperpolarization effect on PMP and this effect could be explained by inhibition of cation channels, which are open under resting conditions. The combination of FA and $\mathrm{K}^{+}$channel inhibitors strongly reduced the STS-induced depolarization of PMP (Figure $2 \mathrm{~b}$ dashed line and Figure $2 \mathrm{c}$, sixth solid bar). All these data suggest that STS activates, as an early response, both $\mathrm{K}^{+}$and cation channels in HeLa cells. We next studied whether these channels have any role in the activation of caspases in these cells.

Role of ion channels in the intrinsic pathway of apoptosis. It has been proposed that STS induces apoptosis by activation of the intrinsic pathway. ${ }^{14,25,26}$ HeLa cells were incubated with z-VAD-fmk (10 or $50 \mu \mathrm{M})$ for $30 \mathrm{~min}$ before induction of apoptosis by 4-h incubation with $1 \mu \mathrm{M}$ STS. Cyt $c$ was released to the cytoplasm in response to STS by a mechanism that does not involve the activation of caspases (Figure 3a). We also studied the role of external $\left[\mathrm{K}^{+}\right]$on STS-induced cyt $c$ release by incubating 
a

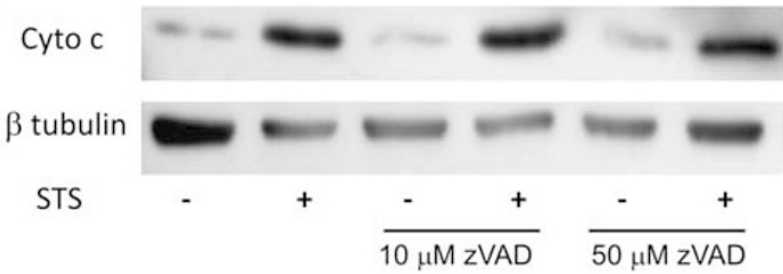

b

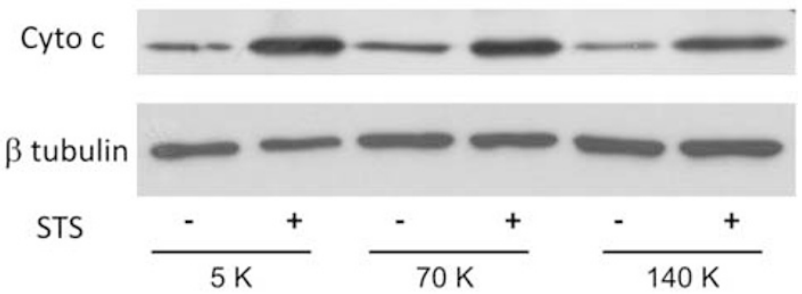

C

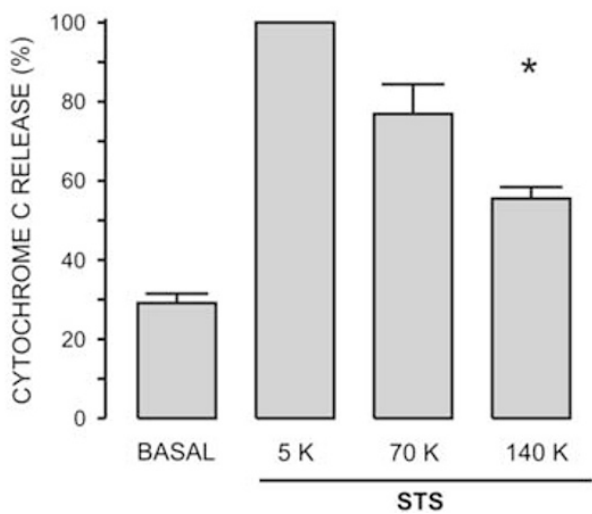

Figure 3 High external $\left[\mathrm{K}^{+}\right]$reduces STS-induced cyt c release. (a) Incubation of cells with either 10 or $50 \mu \mathrm{M} z$-VAD-fmk, a pan-caspase inhibitor, did not block the STS-induced cyt $c$ release $(n=4)$. (b) HeLa cells preincubated in either culture medium $(5 \mathrm{~K})$ or 70 or $140 \mathrm{~K}$ solutions were challenged with STS for $4 \mathrm{~h}$ to assess cyt $c$ release by western blot assay and using $\beta$-tubulin as loading control. Notice that the different external $\left[\mathrm{K}^{+}\right]$did not change the basal release of cyt $c$. (c) The basal level of cyt $c$ was high because of the absence of serum for $24 \mathrm{~h}$ (see Supplementary Figure 1). However, the STS-induced cyt $c$ release was significantly reduced only by $140 \mathrm{~K}(n=4) .{ }^{*} P<0.05$

cells in either 70 or $140 \mathrm{~K}$ solutions (Figure $3 \mathrm{~b}$ ). The addition of STS to cells in $70 \mathrm{~K}$ solution did not inhibit cyt $c$ release (Figure 3c). However, STS-induced cyt $c$ release was significantly reduced when cells were incubated in $140 \mathrm{~K}$ solution (Figures $3 \mathrm{~b}$ and $\mathrm{c}$ ). Preincubation of HeLa cells with the combination of ion channel inhibitors for $30 \mathrm{~min}$ reduced STS-induced cyt $c$ release (Figure $4 \mathrm{a}$ ). This effect was only significant for $\mathrm{K}^{+}$channels inhibitors alone or in combination with FA (Figure 4b). FA alone did not have any effect on STS-induced cyt $c$ release. These data suggest that only $\mathrm{K}^{+}$ channels have a role, still a limited one, in the STS-induced cyt $c$ release.

Role of ion channels in the activation of caspases. Caspase- 9 is activated as a consequence of cyt $c$-mediated apoptosome assembly. ${ }^{27}$ Interestingly, caspase-9 activity was reduced $\sim 40 \%$ by the combination of $\mathrm{K}^{+}$channel inhibitors and FA (Figure 5, open bars). These data are similar to the effect of these inhibitors on the release of cyt $c$, this is in agreement with the importance of cyt $c$ for the

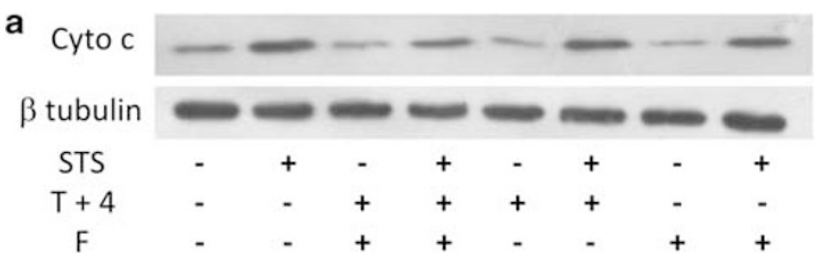

b

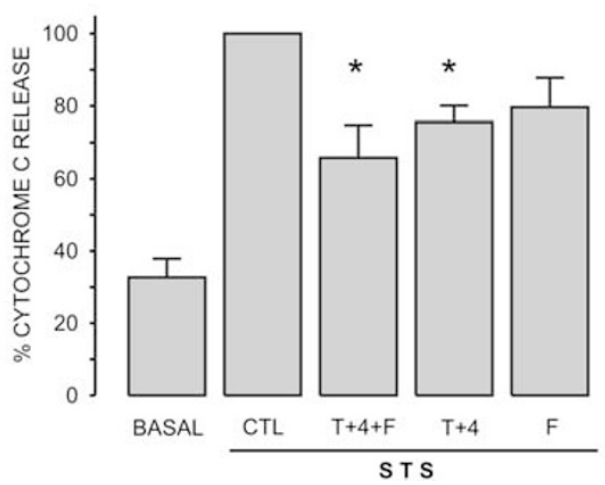

Figure 4 Ion channel inhibitors partially reduced cyt $c$ release. (a) The presence of cyt $c$ in the cytosol was detected by western blot assay. The optical density ratio (cyt $c / \beta$-tubulin) was normalized considering the effect of STS as $100 \%$. (b) FA did not have any effect on STS-induced cyt $c$ release, but the combination of $\mathrm{K}^{+}$ channel inhibitors $(T+4)$ reduced significantly the STS-induced cyt $c$ release, while the addition of FA did not increase any further the inhibitory effect of the combination of $\mathrm{K}^{+}$channel inhibitors $(n=15) .{ }^{*} P<0.05$

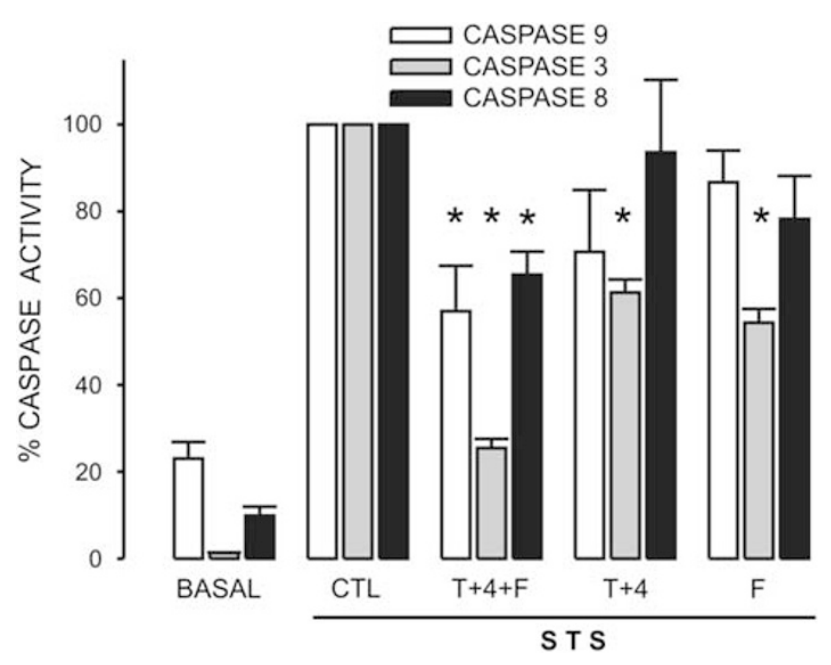

Figure 5 lon channel inhibitors block caspase activation by different mechanisms. Activities of caspase-9 $(n=15),-3(n=18)$ and $-8(n=7)$ induced by STS were assessed in the presence of different ion channel inhibitors. Neither caspase-9 nor caspase-8 were affected by either the combination of TEA ${ }^{+}$and 4AP $(T+4)$ or FA. However, caspase-3 was significantly inhibited by both types of ion channel inhibitors separately or in combination. This combination had an additive effect suggesting that TEA ${ }^{+}$and $4 \mathrm{AP}$ had a different mechanism to inhibit caspase-3 than FA. Interestingly, only this combination of ion channel inhibitors reduced significantly the activation of caspase- 9 and -8 . ${ }^{*} P<0.05$

assembly of the apoptosome, which in turn activates caspase-9.

Caspase- 3 is the main executioner downstream caspase- 9 . We have studied the role of ion channels in STS-induced activation of caspase-3 by two different approaches; one was 
protease activity while the other was PARP degradation. In the case of caspase- 3 activity, the ion channels inhibitors separately reduced STS-triggered caspase-3 activity by $\sim 40 \%$ each one (Figure 5 , gray bars). This is completely different to the effect of ion channel inhibitors on caspase- 9 activity. Moreover, the combination of these ion channels inhibitors significantly reduced by $\sim 80 \%$ STS-induced caspase-3 activity. Importantly, the effect of the combination of ion channel inhibitors is additive, suggesting that these two types of ion channel inhibitors work independently of each other to avoid reduction in the intracellular $\left[\mathrm{K}^{+}\right]$. These data suggest that cation channels might be also a pathway for $\mathrm{K}^{+}$exit from the cell in STS-induced apoptosis, as relevant as $\mathrm{K}^{+}$channels themselves (Figure 5, gray bars).

Additionally, we also studied the participation of ion channels in STS-induced activation of caspase-8. In this case ion channels inhibitors did not have any consistent effect, the variability was so high that there is no significant difference with respect to the basal activity. The combination of these ion channel inhibitors produced a partial but significant reduction ( $\sim 40 \%$ ) in the STS-induced caspase-8 activity (Figure 5, closed bars).

Role of ion channels in degradation of PARP a caspase-3 substrate. The enzyme PARP is one of the proteins cleaved by caspase-3 (Soldani and Scovassi ${ }^{28}$ ). Accordingly, 4-h incubation with STS displayed complete degradation of cytoplasmic PARP (Figure 6a), which was significantly reduced only by the combination of ion channel inhibitors

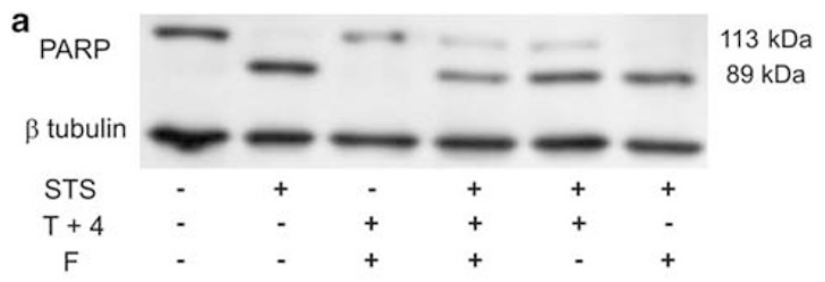

b

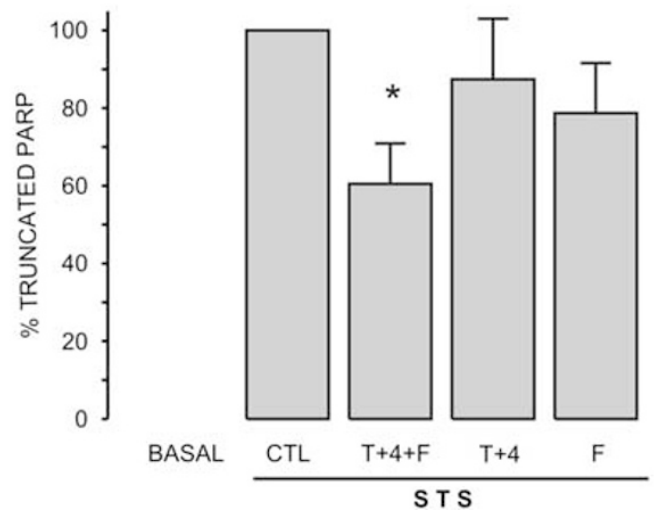

Figure 6 The combination of ion channel inhibitors reduced PARP degradation (a) Supernatant cell extracts were used to assess PARP degradation by western blot and the optical density ratio between the fragment detected at $89 \mathrm{kDa}$ and $\beta$-tubulin resulting of incubating cells with STS was considered as $100 \%$ response. Notice that in control cells truncated PARP is absent while STS-induced PARP degradation completely. (b) None of the ion channels inhibitors alone decreased the normalized level of truncated PARP, but this level was significantly decreased by the combination of TEA ${ }^{+}, 4 \mathrm{AP}$ and $\mathrm{FA}(\mathrm{T}+4+\mathrm{F}, n=9) .{ }^{*} P<0.05$
(Figure 6b). Both approaches, that is, caspase-3 activity and PARP degradation showed that the combination of the two types of ion channel inhibitors had a larger effect than when they were applied separately. Data shown in Figures 5 and 6 argue for PARP being highly sensitive to caspase- 3 activity because only $25 \%$ of caspase- 3 activity (Figure 5 , gray bars) induces practically $60 \%$ degradation of PARP (Figure $6 \mathrm{~b}$ ).

Intracellular $\left[\mathrm{K}^{+}\right]$and $\left[\mathrm{Na}^{+}\right]$changes induced by STS as detected by atomic absorption spectrometry. Collectively, these data suggest that these ion channel inhibitors reduce $\mathrm{K}^{+}$loss associated with apoptosis. To corroborate this hypothesis, we determined the effect of STS and the combination of these ion channel inhibitors on the intracellular $\left[\mathrm{K}^{+}\right]$and $\left[\mathrm{Na}^{+}\right]$after 4-h incubation using atomic absorption spectrometry. STS-induced a significant decrease in the $\left[\mathrm{K}^{+}\right]_{\mathrm{i}}$ from $140 \mathrm{mM}$ to $62.6 \pm 4.3 \mathrm{mM}(n=4$, Figure 7), while the increase in the $\left[\mathrm{Na}^{+}\right]_{\mathrm{i}}$ went from $30 \mathrm{mM}$ to $42.1 \pm 7.5 \mathrm{mM}(n=4)$, which was not large enough to be significant. Unexpectedly, neither the combination of TEA ${ }^{+}$ and $4 \mathrm{AP}$ nor flufenamic alone reduced the $\mathrm{K}^{+}$loss triggered by STS. The combination of these ion channel inhibitors showed a slight recovery of $\left[\mathrm{K}^{+}\right]$, which was too small to reach significance (Figure 7 ). These data corroborate that apoptosis is associated with a reduced $\left[\mathrm{K}^{+}\right]_{\mathrm{i}}$; however, suggest that ion channels inhibitors block caspase- 3 activation by other mechanisms that do not involve the reduction in $\mathrm{K}^{+}$loss.

\section{Discussion}

Apoptosis is clearly associated with PMP depolarization, ${ }^{2,14,29}$ while inhibition of apoptosis by $\mathrm{Bcl}-2$ and $\mathrm{Mcl}-1$ is associated with PMP hyperpolarization. ${ }^{3,4}$ The role of $\mathrm{K}^{+}$ channels in apoptosis has been studied extensively because it

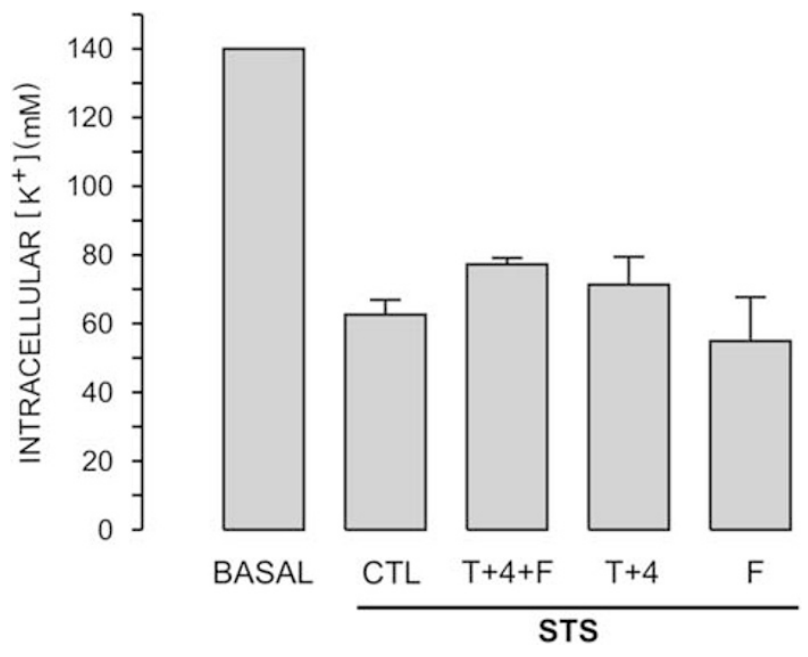

Figure 7 lon channel inhibitors did not decrease STS-induced intracellular $\left[\mathrm{K}^{+}\right]$ reduction. $\left[\mathrm{K}^{+}\right]$detected with atomic absorption spectrometry and normalized by protein was taken to represent $140 \mathrm{mM}$ in the basal condition. STS in a period of $4 \mathrm{~h}$ produced a large and reproducible decrease in the intracellular $\left[\mathrm{K}^{+}\right]$ (CTL response), which was not reversed by the preincubation with either the ion channel inhibitors alone or their combination $(n=4)$ 
is thought to be a pathway for $\mathrm{K}^{+}$exit from the cytoplasm, $5,6,24,29,30$ which is a necessary step for the activation of caspases. ${ }^{5,13,18}$ We have studied the PMP changes induced by STS, a strong activator of apoptosis in HeLa cells. To this end we have used bisoxonol, a fluorescent lipophilic anion, which reports mainly PMP with little interference from the mitochondrial membrane potential and because it has a large ratio of $\% \Delta \mathrm{F} / \mathrm{mV}{ }^{2}$ This approach, particularly at low concentrations, does not modify plasma membrane resistance nor induces cell dialysis, conditions associated with single-cell patch clamp electrophysiology. One caveat of this approach is that PMP values represent the average response of $7.5 \times 10^{5}$ cells in the cuvette. Nevertheless, under our recording conditions the calculated resting PMP was similar to the one reported for HeLa cells using the patch clamp technique. ${ }^{22,23}$ We think that the use of sub- $\mu \mathrm{M}$ bisoxonol has allowed us to detect small changes in the activity of ion channels as an initial response to the application of STS. Importantly, plasma membrane depolarization can be originated by activation of ion channels (either cation or anion) or by inhibition of either $\mathrm{K}^{+}$channel or $\mathrm{Na}^{+} / \mathrm{K}^{+}$pump, to determine which of these two conditions were occurring we used Gram, as a depolarization control. Our data indicate that STS activates both $\mathrm{K}^{+}$ and cation channels in few minutes. The former were sensitive to the combination of $\mathrm{TEA}^{+}-4 \mathrm{AP}$ while the latter to $\mathrm{FA}$, based on the effect of these ion channel inhibitors on the STS-induced changes in PMP.

We have corroborated that reducing the driving force for $\mathrm{K}^{+}$ efflux by increasing external $\left[\mathrm{K}^{+}\right.$] inhibits activation by STS of caspase-9, -3 and -8 in HeLa cells. These data highlight the importance of $\mathrm{K}^{+}$efflux mechanisms in apoptosis, particularly for caspase activation because the ionic strength was kept constant for 5,70 and $140 \mathrm{~K}$ solutions. ${ }^{5,13,18}$ Actually, it has been shown in different cell types that STS activates delayed rectifier $\mathrm{K}^{+}$channels of $\mathrm{K}_{\mathrm{v} 1}$ and $\mathrm{K}_{\mathrm{v} 3}$ subfamilies, which are sensitive to $4 \mathrm{AP}$ and $\mathrm{TEA}^{+}$, respectively. ${ }^{30}$ In this regard, our data show that the combination of $\mathrm{TEA}^{+}$and $4 \mathrm{AP}$ inhibited the STS-induced hyperpolarization response. Nevertheless, our data suggest that the combination of $\mathrm{K}^{+}$channel inhibitors block caspase activation by reducing the STSinduced cyt $c$ release more than inhibiting the loss of $\left[\mathrm{K}^{+}\right]_{\text {i }}$. Accordingly, the $140 \mathrm{~K}$ solution inhibited to a similar extent than $\mathrm{K}^{+}$channel inhibitors the STS-induced cyt $c$ release. Importantly, we did not find any direct effect of these ion channels inhibitors when assessed on previously activated caspase-3 (data no shown).

Flufenamic acid-induced plasma membrane hyperpolarization and totally abolished the activation by STS of the depolarization conductance. FA did not reduce the STSinduced cyt $c$ release and affected neither caspase-9 nor -8 activities. Nevertheless, FA at low concentrations significantly reduced the STS-induced caspase-3 activity by a mechanism that is independent of the one blocked by the combination of $\mathrm{TEA}^{+}$and 4AP. FA has different targets within cells, it is an inhibitor of cyclo oxygenase (COX) 1 and 2 (Lovering et al..$^{31}$ ); of AKR1C3 (Lovering et al. ${ }^{31}$ ) and also of chloride ${ }^{32}$ and cation $^{33}$ channels. None of these targets appears to explain the effect of FA on caspase-3. High doses of nonsteroidal antiinflamatory drugs induce apoptosis by inhibiting COX enzymes and triggering ceramide production. ${ }^{34}$ Moreover, FA would increase the level of prostaglandin $15 d-P G J_{2}$, an apoptosis inducer, by inhibiting the enzyme AKR1C3 that transform $\mathrm{PGD}_{2}$ into $\mathrm{PGF}_{2} \alpha$, the former being the precursor of $15 \mathrm{~d}-\mathrm{PGJ}_{2}$ (Lovering et al. ${ }^{31}$ ). $\mathrm{Ca}^{2+}$-dependent $\mathrm{Cl}^{-}$channels are sensitive to this low concentration of FA. ${ }^{32}$ However, removing external $\left[\mathrm{Ca}^{2+}\right]$ or chelating $\left[\mathrm{Ca}^{2+}\right]_{i}$ did not affect the STS-induced caspase-3 activation (not shown), suggesting that $\mathrm{Ca}^{2+}$-dependent $\mathrm{Cl}^{-}$channels are not involved. Moreover, the inhibition of $\mathrm{Cl}^{-}$channels is not additive with respect to the inhibition of $\mathrm{K}^{+}$channels. ${ }^{8}$ Additionally, blockers of $\mathrm{Cl}^{-}$channels that inhibit AVD, does not always inhibit the activation of caspase-3 (Wei et al. ${ }^{9}$ ). We think that FA is blocking cation channels because it hyperpolarized PMP and induced a transient reduction in the $\left[\mathrm{Ca}^{2+}\right]_{\mathrm{i}}$ (not shown) that reflects the inhibition of $\mathrm{Ca}^{2+}$-permeable cation channels that are active at resting PMP. Nevertheless, these cation channels activated by STS do not represent a substantial $\mathrm{K}^{+}$ exit pathway because FA did not inhibit the STS-induced loss of $\left[\mathrm{K}^{+}\right]_{\mathrm{i}}$. Moreover, our atomic absorption spectrometry data did not show a consistent and substantial increase in the $\left[\mathrm{Na}^{+}\right]_{i}$ in response to STS, most likely because the $\mathrm{Na}^{+}$pump was not yet compromised at $4 \mathrm{~h}$ with STS. Our data also argue that STS-induced $\mathrm{K}^{+}$reduction occurs via either $\mathrm{K}^{+}$channels insensitive to $\mathrm{TEA}^{+}$and $4 \mathrm{AP}$ or most likely via nonelectrogenic mechanism that do not involve $\mathrm{K}^{+}$channels.

In conclusion, $\mathrm{K}^{+}$channel inhibitors blocked caspase-3 activation by inhibiting cyt $c$ release while FA uses a different mechanism. These data highlight the presence of different and multiple mechanisms to control activation of caspases.

\section{Materials and Methods}

Materials. Cell culture reagents were obtained from Gibco-Invitrogen (Grand Island, NY, USA). STS, histamine, TEA ${ }^{+}$or T, 4AP or 4, FA or F, ouabain, Gram, Ac-DEVD-AMC (capase-3 substrate), Ac-DEVD-CHO (caspase-3 inhibitor), Ac-LEDH-AFC (capase-9 substrate), Ac-LEDH-CHO (capase-9 inhibitors), AcIETD-CHO (caspase-8 inhibitor) and protease inhibitor cocktail were purchased from Sigma-Aldrich (St. Louis, MO, USA). Ac-IETD-AMC (caspase-8 substrate) was acquired from Enzo Life Sciences (Lausen, Switzerland). $\mathrm{DiBaC}_{4}(3)$ (bisoxonol) was obtained from Invitrogen (Molecular Probes, Eugene, OR, USA). z-VAD-fmk was bought from Promega (Madison, WI, USA). Mouse anti-cyt $c$ monoclonal antibody (clone 7H8.2C12) and mouse anti-human PARP (clone 4C10-5) were purchased from BD-Pharmigen (Chicago, IL, USA). Mouse anti- $\beta$-tubulin was acquired from ZYMED (Carlsbad, CA, USA).

Cell culture. HeLa cells were cultured in Dulbecco's modified Eagle's medium (with high D-glucose $(4500 \mathrm{mg} / \mathrm{l})$, L-glutamine and sodium pyruvate $(110 \mathrm{mg} / \mathrm{l})$ ) supplemented with $5 \%$ fetal bovine serum, $3 \%$ newborn calf serum and penicillinstreptomycin. Cells were cultured for $24 \mathrm{~h}$ without serum before inducing apoptosis by the addition of $1 \mu \mathrm{M}$ STS for a period of $4 \mathrm{~h}$. The absence of serum increased for $\sim 30 \%$ the release of cyt $c$ to the cytoplasm with respect to the effect of STS (Supplementary Figure 1). Nevertheless, cell viability was always $\geq 95 \%(0.08 \%$ Trypan blue exclusion).

PMP determination with bisoxonol. HeLa cells that have been cultured in the absence of serum for $24 \mathrm{~h}$ were harvested, washed and the cell pellet resuspended in saline solution containing: $121 \mathrm{mM} \mathrm{NaCl}, 5.4 \mathrm{mM} \mathrm{KCl}, 0.8 \mathrm{mM}$ $\mathrm{MgCl}_{2}, 1.8 \mathrm{mM} \mathrm{CaCl}_{2}, 6 \mathrm{mM} \mathrm{NaHCO}_{3}$ and $25 \mathrm{mM} \mathrm{Hepes}$, at $\mathrm{pH} 7.3(\mathrm{NaOH})^{35}$ at a density of $3 \times 10^{6} \mathrm{cells} / \mathrm{ml}$. To determine PMP, $125 \mathrm{nM}$ bisoxonol was added to the saline solution followed by $3 \times 10^{5} \mathrm{celll} / \mathrm{ml}$ and fluorescence signal was excited at $490 \mathrm{~nm}$ and collected at $530 \mathrm{~nm}$ using a QM-8 spectrofluorometer (PTI). Once the fluorescence signal has leveled off, $\mathrm{K}^{+}$conductance was increased with $100 \mu \mathrm{M}$ histamine, which induces plasma membrane hyperpolarization (Supplementary Figure 2) and the $\mathrm{K}^{+}$equilibrium potential was changed by applying five consecutive additions of $25 \mathrm{mM} \mathrm{KCl}$ (Supplementary Figure 2). Finally, $1 \mu \mathrm{M} \mathrm{Gram}$ 
was added as depolarization control. As histamine increased the $\mathrm{K}^{+}$conductance, we can use Nernst equation to calculate PMP as the equilibrium potential at different external $\left[\mathrm{K}^{+}\right]$. These data were fitted by the following equation $\% F=k \log _{10}(\mathrm{Er} /(\mathrm{Em}$ $-h))$ where $\% F$ is $\%(\Delta F / F 0)$, Fo is fluorescence signal at rest, $k=$ slope, $h=$ constant, $\mathrm{Er}=\mathrm{PMP}$ when $\% \mathrm{~F}$ is zero, $\mathrm{Em}=\mathrm{PMP}$ for different $\left[\mathrm{K}^{+}\right]$. From the fitting of these data to the equation, we derived the values for $k, \mathrm{Er}$ and $h$ for each experiment (passage of cells) and used these values to calculate PMP from the value of $\mathrm{Em}$ using the following relationship $\mathrm{Em}=\left[\mathrm{Er} / 10^{(\% \mathrm{~F} / \mathrm{k})}\right]+h$. To determine the effect of STS on the PMP, bisoxonol was added to saline solution alone or with ion channel inhibitors (either the combination of $10 \mathrm{mM} \mathrm{TEA}^{+}$and $2 \mathrm{mM} 4 \mathrm{AP}$ or $50 \mu \mathrm{M} \mathrm{FA}$ or all three together) followed by cell addition. In the case of the pancaspase inhibitor (z-VAD-fmk), this chemical was incubated with cells for $30 \mathrm{~min}$ before initiating PMP recording. Once the fluorescence signal leveled off after cell addition, $1 \mu \mathrm{M}$ STS was added and the bisoxonol fluorescence signal was recorded for 5-10 min before the application of $1 \mu \mathrm{M}$ Gram as depolarization control.

Induction of apoptosis for cells in culture. Confluent HeLa cells that were cultured without serum for $24 \mathrm{~h}$ were preincubated for $30 \mathrm{~min}$ with or without the combination of $\mathrm{K}^{+}$channel inhibitors, $50 \mu \mathrm{M} \mathrm{FA}$, all three ion channel inhibitors, 10 or $50 \mu \mathrm{M} z$-VAD-fmk before STS. For experiments with different external $\left[\mathrm{K}^{+}\right]$ cells were left for $30 \mathrm{~min}$ in culture medium $(5 \mathrm{~K})$, in $70 \mathrm{~K}$ saline solution containing in $\mathrm{mM}: 25$ Hepes, $70 \mathrm{KCl}, 51.5 \mathrm{NaCl}, 0.8 \mathrm{MgCl}_{2}, 1.8 \mathrm{CaCl}_{2}, 6 \mathrm{NaHCO}_{3}, 5.5$ glucose at $\mathrm{pH} 7.3$ and in $140 \mathrm{~K}$ saline solution containing in mM: 25 Hepes, $126.5 \mathrm{KCl}, 0.8$ $\mathrm{MgCl}_{2}, 1.8 \mathrm{CaCl}_{2}, 6 \mathrm{NaHCO}_{3}, 5.5$ glucose at $\mathrm{pH} 7.3$ before inducing apoptosis with STS. After 4-h incubation with STS, cell were lysed and lysates were used for caspase assays, western blot assay and determination of intracellular $\left[\mathrm{K}^{+}\right]$and $\left[\mathrm{Na}^{+}\right]$with atomic absorption spectrometry.

Detection of caspase activity. In all caspase assays, cells cultured in six-well plates were lysed with $500 \mu$ l of caspase lysis buffer per well containing in $\mathrm{mM}$ : 50 Hepes, 5 DTT and $1 \%$ Triton X-100 and well plate were stirred on ice for $30 \mathrm{~min}$ before collecting the samples.

Caspase-3 activity. Assay was carried out according to the specifications in the kit with slight variations. Caspase-3 assay buffer contained in mM: 20 Hepes, 5 DTT, 2 EDTA and $0.1 \%$ Triton X-100 at pH 7.4. Assay buffer was supplemented with $1 \mu \mathrm{M}$ Ac-DEVD-AMC (caspase-3 substrate) with or without $2 \mu \mathrm{M}$ Ac-DEVD-CHO (caspase-3 inhibitor) and $50 \mu \mathrm{l}$ of cell lysate. This mix was incubated at room temperature for $90 \mathrm{~min}$. Caspase-3 activity was determined subtracting to the fluorescence signal to the one obtained in the presence of caspase inhibitor. The fluorescence value obtained from cells incubated with STS was considered as $100 \%$ response.

Caspase-9 activity. Assay was carried out as previously described ${ }^{36}$ with slight differences. Caspase-9 assay buffer contained in mM: 100 MOPS, 10 DTT, 0.5 EDTA, $0.1 \%$ Triton X-100 at pH 6.5 and $10 \%$ glycerol. Assay buffer with $100 \mathrm{ml}$ of cell lysate was preincubated for $30 \mathrm{~min}$ at $32^{\circ} \mathrm{C}$ before supplementing with $1 \mu \mathrm{M}$ Ac-LEDH-AFC (caspase-9 substrate) with or without $2 \mu \mathrm{M} \mathrm{Ac-LEDH-CHO}$ (caspase-9 inhibitor) and incubated at $32{ }^{\circ} \mathrm{C}$ for $24 \mathrm{~h}$. Fluorescence signal was treated similarly as for caspase-3 assay.

Caspase-8 activity. Assay was carried accordingly to the kit manufacturer with slight differences. Assay buffer contained in mM: 20 Hepes, 5 DTT, 2 EDTA, $5 \%$ sucrose and $0.1 \%$ Triton $\mathrm{X}-100$ at $\mathrm{pH} 7.4$. Assay buffer was supplemented with $1 \mu \mathrm{M} \mathrm{AC-IETD-AMC} \mathrm{(caspase-8} \mathrm{substrate)} \mathrm{and} \mathrm{with} \mathrm{or} \mathrm{without} 2 \mu \mathrm{M} \mathrm{AC-IETD-CHO}$ and $50 \mu$ of cell lysate. This mix was incubated at $32^{\circ} \mathrm{C}$ for $24 \mathrm{~h}$. The fluorescence signal was treated similarly as for caspase- 3 assay.

Cyt $c$ release and PARP fragmentation. Cells in PBS with protease inhibitor cocktail were harvested with a Cell Lifter (Costar, Corning, Corning, NY, USA) and microcentrifuged at $10^{4} \times g$ for 30 min to separate supernatant (cytosolic fraction) from pellet (particulate fraction). In all, $20 \mu \mathrm{g}$ of protein per lane were separated by SDS-PAGE in discontinuous gradient gels, blotted in PVDF membranes and revealed with anti-cyt $c$ antibody $(1: 2000)$, anti-PARP antibody $(1: 1000)$ and anti- $\beta$-tubulin antibody $(1: 5000)$ as loading control. Optical density for each band was divided by the corresponding optical density of $\beta$-tubulin and this ratio in the presence of STS was taken as $100 \%$.

STS-induced changes in the $\left[\mathrm{K}^{+}\right]_{\mathrm{i}}$ and $\left[\mathrm{Na}^{+}\right]_{\mathrm{i}}$ using atomic absorption spectrometry. Cells were washed with cold D-mannitol (6\%) twice followed by the addition of $100 \mu \mathrm{l}$ of $\mathrm{HNO}_{3} 0.1 \mathrm{~N}$ and harvested with Cell Lifter (Costar, Corning) and protein concentration determined. Sample $\left[\mathrm{K}^{+}\right]$and $\left[\mathrm{Na}^{+}\right]$ were determined based on standard $\mathrm{K}^{+}$and $\mathrm{Na}^{+}$curves in $0.2 \% \mathrm{CsCl}$ using a PerkinElmer (Waltham, MA, USA) AAnalyst 200 spectrometer. The internal ion concentration detected was normalized by corresponding protein concentration and assumed to represent $140 \mathrm{mM}\left[\mathrm{K}^{+}\right]_{\text {i }}$ or $30 \mathrm{mM}\left[\mathrm{Na}^{+}\right]_{\text {i. }}$.

Statistical analyses. All data are presented as mean \pm S.E.M., where $n$ represent different experiment (different cell passage). Statistical significance was evaluated by ANOVA and Tukey's tests. In all cases the STS-induced response was significantly different to basal level, so this analysis is not shown. * means that $P<0.05$ when the tested condition was different with respect to the STS-induced response, except for Figure 2c.

\section{Conflict of interest}

The authors declare no conflict of interest.

Acknowledgements. We thank Conacyt for fellowship 162555 to E BenitezRangel and grant 44699 to A Guerrero-Hernández.

1. Wyllie $\mathrm{AH}$. Where o death, is thy sting? A brief review of apoptosis biology. Mol Neurobiol 2010; 42: 4-9.

2. Bortner $C D$, Gomez-Angelats M, Cidlowski JA. Plasma membrane depolarization without repolarization is an early molecular event in anti-Fas-induced apoptosis. J Biol Chem 2001; 276: 4304-4314.

3. Gilbert MS, Saad AH, Rupnow BA, Knox SJ. Association of BCL-2 with membrane hyperpolarization and radioresistance. J Cell Physiol 1996; 168: 114-122.

4. Wang L, Zhou P, Craig RW, Lu L. Protection from cell death by mcl-1 is mediated by membrane hyperpolarization induced by K(+) channel activation. J Membr Biol 1999; 172: 113-120.

5. Platoshyn O, Zhang S, McDaniel SS, Yuan JX. Cytochrome $\mathrm{c}$ activates $\mathrm{K}^{+}$channels before inducing apoptosis. Am J Physiol Cell Physiol 2002; 283: C1298-C1305.

6. Yu SP, Yeh CH, Sensi SL, Gwag BJ, Canzoniero LM, Farhangrazi ZS et al. Mediation of neuronal apoptosis by enhancement of outward potassium current. Science 1997; 278: 114-117.

7. Bortner $\mathrm{CD}$, Hughes Jr FM, Cidlowski JA. A primary role for $\mathrm{K}^{+}$and $\mathrm{Na}^{+}$efflux in the activation of apoptosis. J Biol Chem 1997; 272: 32436-32442.

8. Maeno E, Ishizaki Y, Kanaseki T, Hazama A, Okada Y. Normotonic cell shrinkage because of disordered volume regulation is an early prerequisite to apoptosis. Proc Natl Acad Sci USA 2000; 97: 9487-9492.

9. Wei L, Xiao AY, Jin C, Yang A, Lu ZY, Yu SP. Effects of chloride and potassium channel blockers on apoptotic cell shrinkage and apoptosis in cortical neurons. Pflugers Arch 2004; 448: 325-334.

10. Arrebola F, Canizares J, Cubero MA, Crespo PV, Warley A, Fernandez-Segura E. Biphasic behavior of changes in elemental composition during staurosporine-induced apoptosis. Apoptosis 2005; 10: 1317-1331.

11. Bortner CD, Cidlowski JA. Caspase independent/dependent regulation of $\mathrm{K}(+)$, cell shrinkage, and mitochondrial membrane potential during lymphocyte apoptosis. J Biol Chem 1999; 274: 21953-21962.

12. Bortner CD, Sifre MI, Cidlowski JA. Cationic gradient reversal and cytoskeletonindependent volume regulatory pathways define an early stage of apoptosis. $J$ Biol Chem 2008; 283: 7219-7229.

13. Hughes Jr FM, Bortner CD, Purdy GD, Cidlowski JA. Intracellular $\mathrm{K}^{+}$suppresses the activation of apoptosis in lymphocytes. J Biol Chem 1997; 272: 30567-30576.

14. Dussmann H, Rehm M, Kogel D, Prehn JH. Outer mitochondrial membrane permeabilization during apoptosis triggers caspase-independent mitochondrial and caspase-dependent plasma membrane potential depolarization: a single-cell analysis. J Cell Sci 2003; 116: 525-536.

15. Cain K, Langlais C, Sun XM, Brown DG, Cohen GM. Physiological concentrations of $\mathrm{K}^{+}$ inhibit cytochrome c-dependent formation of the apoptosome. J Biol Chem 2001; 276: 41985-41990

16. Karki P, Seong C, Kim JE, Hur K, Shin SY, Lee JS et al. Intracellular K(+) inhibits apoptosis by suppressing the Apaf-1 apoptosome formation and subsequent downstream pathways but not cytochrome c release. Cell Death Differ 2007; 14: 2068-2075.

17. Thompson GJ, Langlais C, Cain K, Conley EC, Cohen GM. Elevated extracellular $\left[\mathrm{K}^{+}\right]$ inhibits death-receptor- and chemical-mediated apoptosis prior to caspase activation and cytochrome c release. Biochem J 2001; 357: 137-145.

18. Feeney B, Clark AC. Reassembly of active caspase- 3 is facilitated by the propeptide. J Biol Chem 2005; 280: 39772-39785.

19. Tang D, Lahti JM, Kidd VJ. Caspase-8 activation and bid cleavage contribute to MCF7 cellular execution in a caspase-3-dependent manner during staurosporine-mediated apoptosis. J Biol Chem 2000; 275: 9303-9307. 
20. Wurstle ML, Laussmann MA, Rehm M. The caspase-8 dimerisation/dissociation balance is a highly potent regulator of caspase-8, $-3,-6$ signalling. $J$ Biol Chem 2010; 285: 33209-33218.

21. Sauve R, Simoneau C, Parent L, Monette R, Roy G. Oscillatory activation of calciumdependent potassium channels in HeLa cells induced by histamine $\mathrm{H} 1$ receptor stimulation: a single-channel study. J Membr Biol 1987; 96: 199-208.

22. Stein MA, Mathers DA, Yan H, Baimbridge KG, Finlay BB. Enteropathogenic Escherichia coli markedly decreases the resting membrane potential of Caco-2 and HeLa human epithelial cells. Infect Immun 1996; 64: 4820-4825.

23. Szabo I, Brutsche S, Tombola F, Moschioni M, Satin B, Telford JL et al. Formation of anion-selective channels in the cell plasma membrane by the toxin VacA of Helicobacter pylori is required for its biological activity. EMBO J 1999; 18: 5517-5527.

24. Remillard CV, Yuan JX. Activation of $\mathrm{K}^{+}$channels: an essential pathway in programmed cell death. Am J Physiol Lung Cell Mol Physiol 2004; 286: L49-L67.

25. Nicolier M, Decrion-Barthod AZ, Launay S, Pretet JL, Mougin C. Spatiotemporal activation of caspase-dependent and -independent pathways in staurosporineinduced apoptosis of p53wt and p53 mt human cervical carcinoma cells. Biol Cell 2009; 101: 455-467.

26. Tafani M, Minchenko DA, Serroni A, Farber JL. Induction of the mitochondrial permeability transition mediates the killing of HeLa cells by staurosporine. Cancer Res 2001; 61 . 2459-2466.

27. Johnson CR, Jarvis WD. Caspase-9 regulation: an update. Apoptosis 2004; 9: 423-427.

28. Soldani C, Scovassi Al. Poly (ADP-ribose) polymerase-1 cleavage during apoptosis: an update. Apoptosis 2002; 7: 321-328.

29. Franco R, Bortner CD, Cidlowski JA. Potential roles of electrogenic ion transport and plasma membrane depolarization in apoptosis. J Membr Biol 2006; 209: 43-58.
30. Storey NM, Gomez-Angelats M, Bortner CD, Armstrong DL, Cidlowski JA. Stimulation of Kv1.3 potassium channels by death receptors during apoptosis in Jurkat T lymphocytes. J Biol Chem 2003; 278: 33319-33326.

31. Lovering AL, Ride JP, Bunce CM, Desmond JC, Cummings SM, White SA. Crystal structures of prostaglandin $\mathrm{D}(2)$ 11-ketoreductase (AKR1C3) in complex with the nonsteroidal anti-inflammatory drugs flufenamic acid and indomethacin. Cancer Res 2004; 64: $1802-1810$

32. Greenwood IA, Leblanc N. Overlapping pharmacology of $\mathrm{Ca}^{2+}$-activated $\mathrm{Cl}^{-}$and $\mathrm{K}^{+}$ channels. Trends Pharmacol Sci 2007; 28: 1-5.

33. Gogelein H, Dahlem D, Englert HC, Lang HJ. Flufenamic acid, mefenamic acid and niflumic acid inhibit single nonselective cation channels in the rat exocrine pancreas. FEBS Lett 1990; 268: 79-82.

34. Chan TA, Morin PJ, Vogelstein B, Kinzler KW. Mechanisms underlying nonsteroidal antiinflammatory drug-mediated apoptosis. Proc Natl Acad Sci USA 1998; 95: 681-686.

35. Bootman MD, Cheek TR, Moreton RB, Bennett DL, Berridge MJ. Smoothly graded $\mathrm{Ca}^{2+}$ release from inositol 1,4,5-trisphosphate-sensitive $\mathrm{Ca}^{2+}$ stores. J Biol Chem 1994; 269: 24783-24791.

36. Garcia-Calvo M, Peterson EP, Rasper DM, Vaillancourt JP, Zamboni R, Nicholson DW et al. Purification and catalytic properties of human caspase family members. Cell Death Differ 1999; 6: 362-369.

Cell Death and Disease is an open-access journal published by Nature Publishing Group. This work is licensed under the Creative Commons Attribution-Noncommercial-No Derivative Works 3.0 Unported License. To view a copy of this license, visit http://creativecommons.org/licenses/by-nc-nd/3.0/

Supplementary Information accompanies the paper on Cell Death and Disease website (http://www.nature.com/cddis) 